DOI https://doi.org/10.36059/978-966-397-110-0/143-159

\title{
MAIN FACTORS OF STRENGTHENING THE ROLE OF MORAL PRINCIPLES IN UKRAINIAN SOCIETY
}

\section{Tymoshenko T.S.}

Ukraine is experiencing rather hard times. Severe economic and political situation leads to the further impoverishment of people. And all this complex of socio-economic problems is getting complicated by deeper moral-cultural crisis resulted in spiritual degradation of society, loss of value orientations and further moral decline of our people. It is known that the culture and spirituality are civilization features of any nation without which it is not possible to exist. The nation where spiritualmoral values are ignored destined to death. And it is only a matter of time. That is why under such conditions it is essential to activate efforts on increase of Ukrainian people's moral-spiritual level, the formation of a durable system of deep moral-spiritual values in them because it is these values that form the basis of motivation field of both personality and society in general. Something that governs an individual person or a certain society in their actions reflects their deep essence rather clearly. If a personality or societies professes high moral-humanistic values, then the goals and means of their achievement will be rather high and moralhumanistic. Only this way we can achieve step-by-step economic, political and spiritual rise of our country because these domains are quite tight interconnected.

Global changes in Ukrainian politics lead to disturbances in economics, determining even more catastrophic phenomena in moralcultural domain. Low cultural and moral level of society in general as well as its all structural elements in particular, leads to creation of utilitarian value system based on which a person or a certain community cares only about personal interests not taking into account the needs of other people and society as a whole. Of course, it is important to solve economic and political problems but excessive attention should be paid to revival of society's cultural domain, moral and moral relationships formation because the development of Ukrainian nation is not possible without them. 
Predicting political processes in Ukraine in $21^{\text {st }}$ century, it is important to take into account the moral choice of the problem, namely, the correlation of political means used by political ethics. According to many evaluations, the present crisis in Ukraine is primarily a moral crisis, the result of insufficient developed political-ethical consciousness. To a certain degree such its state is resulted from historical conditions where political ethics has been formed. From the very beginning the political ethics of Ukrainian people showed tolerate attitude to diverse forms of political institutions and has been based on pure democratic principles. Political consciousness has perceived a certain political-ethical order with a wide variety of mixed political institutions inherent in it for a long time that is now identified with a political ideal of power division. For example, a triune scheme of unification of various power forms was a peculiar political-ethical order. In Kievan Rus every principality had ethical-political scheme, namely: princes- boyars- veche that is monarchic, aristocratic and democratic elements.

Zaporozhian Sich was a peculiar example of political-ethical behavior. For example, a person who was elected as a hetman or ataman before a military campaign had to refuse from the honor given twice and agreed only for the third time after invitations with long-lasting persuasion, ritual bad language and threats. The election ceremony ended with the placement of handful of soil on the head of a chosen person by old Cossacks, symbolizing the fidelity of the chosen to society. According to Ivan Ogienko, "all Ukrainian life, all the order of the house, all our state system - all this was always democratic. The state of servants was never oppressed in our old nobility - they were always free and equal to everyone ... All the cities in the Ukraine - in the old times, had full selfgovernment: all the officials, all state servants were elective, elected from town dwellers themselves and always reported to that community that elected them."1

The role of the church in life of a contemporary Ukrainian society was of great significance, which activities also showed democratic traditions, being an essential characteristic of political culture: "Metropolitan was always chosen by free votes, and the Patriarch of Constantinople only blessed him. In Ukraine, in church life, there was an elective principle everywhere: priests, bishops, archimandrites, heguman,

\footnotetext{
${ }^{1}$ Огієнко Іван. Українська культура. Коротка історія культурного життя українського народа. К.: Абрис, 1991. -272 с. Ст. 60.
} 
and even metropolitans were chosen by free voices."2 So, it is obvious that ordinary people had election rights, a certain political experience and political system in Ukraine.

We can not deny the fact that the Christian Church and Christianity in general played not a last role in the functioning of Ukrainian state as well as in the management of Ukrainian people at all times. Unfortunately, this point can not yet be taken into account by our contemporary statesmen due to certain well-known objective reasons. One of the most important reasons for this is lack of a single national church that would unite and gather people for solving common problems.

Speaking about the influence of the Christian church and religion on Ukrainian society in general at all times, it should be said that there is a certain stereotype, a standard attitude towards religion and religious organizations among Ukrainian citizens. However, according to sociological research, public opinion about religion, its place and role in the life of Ukrainian society has changed significantly. In particular, among a large part of the population sympathy for the socio-cultural and charitable work of religious organizations has increased. Even today, the majority tends to evaluate religion from the standpoint of its indisputable nature, extremely important role in the process of spiritual and national revival of Ukrainian people. We can hope that this process will be lasting and both the church and the society will facilitate its catalyzation.

Speaking about such national misfortune as a spiritual and cultural decline of our society, the growth of crime and other problems caused by a difficult socio- economic situation, it can be asserted that the Christian church could take part in their overcoming, the main principles of which, along with other world religious teachings and ideologies, became the foundation of all modern culture and moral.

However, depriving people of voice, autonomy, and initiative, Russian autocratic government systematically carried out a policy of weakening the ethical consciousness that strengthened its own power, but prevented the intellectual development of both Russian and Ukrainian people. "Under the influence of socio-economic, political, cultural conditions of life in Russian Empire, - notes V. Bebik- through the introduction of Moscow state system and cancellation of Ukrainian autonomy (in 110 years after the 1654 agreement) democratic values of

\footnotetext{
${ }^{2}$ Огієнко Іван. Українська культура. Коротка історія культурного життя українського народа. К.: Абрис, 1991. - 272 с. Ст. 62.
} 
Ukrainian society are gradually "wiped out" by socially-political and psychological directives of Russian, but, in fact, Eastern (or Asian) political culture." The ethics of autocratic government was nothing more than an attempt to concentrate political ethics "in a single pair of hands" and, accordingly, releasing people from it. And someone, who is not responsible, as it is known, remains outside ethical relations. ${ }^{3}$

The October upheaval of 1917 became a peculiar justice on the political ethical norms. This "justice" existed in the sense that, in fact, all the former ideals were rejected, and a communist ideal was put forward by the imperative, which "released" not a single generation of people from universal human ethical norms, ultimately changing their ethical-political worldview. Ukrainian aristocracy as the main "genetic" holder of ethical values was almost destroyed. And according to the well-known Spanish philosopher J. Ortega y Gasset, disintegration of aristocracy is equivalent to society collapse. The absence of the "best ones" is the fatal spinelessness of the nation, leading to its breakdown, social chaos, because the true aristocracy of spirit is an integral part of the soul, in which there are permanent and obligatory ethical qualities that have become certain established communications in the process of mankind history.

The new political elite "from people" were deprived of moral-ethical concepts. In Bolshevik sense, "class moral" was only a hidden attempt to deprive a policy of ethical dimension. It solved its political problems by destroying its opponents. For example, a bright phenomenon in the process of establishing a new political ideal after October 1917 upheaval was the ethical and legal nihilism, under which the right was considered a defective form of regulation of social life, an institution of the past that was borrowed from the old exploiting classes only for a certain time and because of necessity. Legal norms were entirely denied, and the protection of personal independence - civil, labor, property, and creative - was considered insignificant. Social and political paternalism was distributed (understanding of "parental" care over all aspects of social life), aimed at carrying out authoritarian, and often coercive care of working people.

Ethical-legal nihilism celebrated its first triumph on January 5, 1918, when the Constituent Assembly was disrupted. It was during this period that the subordination of laws to the ideal of "the future happiness of all mankind" was laid. It looked like it was left aside that in the name of a

\footnotetext{
${ }^{3}$ Бебик В. Наша політична культура // Політологічні читання. - 1992. - №1. - Ст. 20.
} 
created ideal, the awareness of separate human life value was lost, and skills only for the military-terrorist way of solving any urgent problems were developed that had survived for many years. With the destruction of political elite, concentrating all the political ethics in its consciousness, the country was doomed to decades of political cruelty. Everything that was dear to the nation was subjected to violence. The irrevocability of moral grounds, namely, values that should have remained intact under all circumstances, was being destroyed. Political consciousness became saturated with destructive content, radicalism, cynicism.

Political ethics in Soviet times was based on the ethics of the party nomenclature, which was interested, on the one hand, in the indifferentism (indifference) of political-moral consciousness of people, and, on the other hand, it brought the ideological psychosis associated with the socalled class struggle, the confrontation between two political systems, with "ideological sabotage of decaying capitalism against the progressive world". The Communist Party of Soviet Union developed its internal party ethics, based on regulated principles.

The German-Soviet war significantly changed the social consciousness and, at the same time, the foundations of political ethics. The realization of ideals of that time was sincerely associated with the personality of I. Stalin, and then M. Khrushchev. However, the revelation of Stalin personality's cult, a certain change in the political regime towards democracy has not substantially shaken the foundations of political ethics of a totalitarian society.

In judicial and law practice of 60-70s, there was another danger associated with one of the postulates of ethical and legal nihilism. The utopian idea of close proximity of communism, which had penetrated many of the program documents of those years, gave reasons to suppose that society came close to the period of "dying of law", and this process could be forced by replacing punishment of the court with moral and educational sanctions of party and public organizations, which were practiced.

Ethical and legal nihilism appeared not only in theoretical considerations. It substantially deformed the language. The word "bourgeois" was combined with the word "law" as a negative epithet. The same applies to concepts such as "parliamentarism", "legal entity", "formal equality". Even the word "personality" had a negative shade, and 
the word "mass" - a huge significance. It united with the words "folk", "labor", "revolutionary" and practically lost the socially critical content inherent in it from the old times. Everyone who in 1960s showed national patriotism, activity in public life, was subjected to repression. An ideological attack against "idealizing the past of Ukrainian people" was intensified. It was considered unethical to use epithets such as "Ukrainian", "Cossack", the phrase "Zaporozhian Sich", etc.

Already after the fall of CPSU power, the nomenclature still remained the main holder of ethical-political consciousness. On this occasion, "bloodless" revolutions, which preserved the party elites in power in many post-socialist countries, provided some succession in the field of political ethics. However, new upheavals, even if they facilitated the recovery of social system, did not strengthen political ethics.

At the present stage, Ukraine has declared about a tendency to transfer all responsibility for the nation destiny to the power, which is evidence of insufficient political and historical awareness of its active holders. The falseness of this point of view is explained by the fact that the state power today is corroded by corruption, clan system of bureaucracy, its merger with shadow capital and criminality. The ideal of civil society has become much more distant. All these problems are ethical, giving the rise to disbelief in the existing power, complicating the reforms.

Ukrainian political culture also demonstrates its inability to harmonize social order, organized institutional relations under the conditions of weakening traditional hierarchical power-legal relations. According to ideological parameters, it has still been under the influence of a socialist ideal (equalization, collectivism, totalitarianism), while demonstrating the tendency toward a certain deideologization.

The political culture of modern Ukraine is a culture of marginal society (vested with mutually exclusive features), manifested in orientation of citizens on mutually contradicting values: $33 \%$ believe that the capitalist system is most favorable to the republic, $25 \%$ do not have a definite position, and only $42 \%$ are convinced, that Western type of development do not satisfy them. This phenomenon is associated with an ambivalent (split) social consciousness. So, instead of mobilizing Ukrainian society there is a peculiar disorder. 
The democratic culture of the community is a worldview and moral state of a person characterized by a sense of belonging to a particular state, a loyal attitude to its institutions and laws, appraisal of own dignity in relations with the authorities, knowledge and respect for human rights, the virtues of civil society, readiness and ability to require observance of own rights, demand from the state to fulfill its function, loyal, responsible attitude towards own obligations before the state, and finally, patriotism. Patriotism, a feeling love to own homeland, the respect of its history, the ability to care about its present, the destiny of compatriots, is outside the politics, it is a high moral value. The true patriot honors and loves his homeland not only in times of its prosperity, but also in times of difficulties, when the authority is possessed by unworthy, in his opinion, people. The patriot loves the country, the homeland, and not a state or power. Love for the homeland in spite of any authority is moral and civic virtue. Patriotism is considered a sign of high moral of a citizen until it becomes an arrogant chauvinism as long as a person is able to appreciate the same love of other person to the country, to respect other person's moral, patriotic feelings.

Another component of moral-political culture of society is the knowledge of how the political system of society is organized, which are the moral prerogatives and functional capabilities of its components, how it is to be influenced, appealed to state structures and official institutions, which ways and methods of interaction are acceptable and the most effective here. The culture of political involvement is determined by the level of knowledge and ideas of citizens about the essence of politics, its moralistic fullness, the relation of political forces, political regulations, procedures and technologies, and the ability to use this knowledge in practice. Modern political culture is an expression of ideas of plurality of social and political life, ideas of spirituality and moral level of society, diversity of legal forms of political confrontation, appreciation of the integrity and moral stability of society.

Peculiarities of political ethics of Ukrainian society are determined by the geographical position of our country on the so-called breakdown of cultures, socio-political orientations: if the central, western regions are guided by European standards, then in the East Euro-Asian standards are more popular. Moreover, if the goals and ideals of Ukrainian community are close to the Western, then the way of life is closer to the Eastern one. 
Ukraine has always strived to participate in the European political game, but it often used methods of the Eastern origin.

Some scientists warn against the unambiguous attribution of Ukraine to Western European civilization, which, by the way, has been and is not homogeneous. It is known, that neither Hegel nor Marx and other contemporary, and modern Western European scholars, do not attribute Ukraine to Europe in this terms. Prevalence of European factor in the scientific literature may be due to the fact that it is more or less researched, and the eastern influence remains almost a virgin soil.

The political ethics of modern Ukrainian society is largely determined by lack of control under the authorities, the priority of state goals to the rights of the individual, the superiority of pragmatic considerations to system guarantees, the prevalence of traditionalism over dynamism. For example, at the request of the European public in Ukraine, the death penalty was cancelled. This is a truly serious step not only from the point of view of political ethics, but also universal one. However, the funds for the life of convicts should be found by the head of the colony.

A lot of examples of history convinced that eastern politics is focused on power, strength, and not on law or political ethics. Ukraine often had to deal with such policy, and of course, in its political ethics it is possible to find many "Asian" traces - autocracy, gerontocracy, patriarchism, secret diplomacy, susceptibility to force methods, etc.

In this regard, it is important to identify some contradictions between politics and morality, breaking the integrity of political ethics in the public consciousness. These contradictions are the background on which political relations in society are formed.

The first of these is the moral-psychological contradiction between "the desirable and valid". A very long gap between them almost always marks the split, the inner crisis of personality, and often slyness and ludicrous soul. The same thing happens if people can not organize their lives according to their own principles, can not agree their desire with the social order. The phenomena of such disagreement were observed in the past, for example, when society did not see the implementation of Khrushchev's promise "about the final construction of communism". They are also traced in the present Ukrainian history. Thus, the adoption of the new Constitution of Ukraine gave rise to the statement on the initial period completion on the formation of a democratic, social and law- 
governed state, beginning the transition to the next period, that is "the implementation of principles and norms of the Constitution in a real life of society and state, in a life of each person who lives in Ukraine". However, after some time, a contradiction between declared norms, the real possibility and the desire for their implementation has appeared with a new severity. First of all, it is about a tripartite verbal structure: "democratic, social, law-governed state", which is still unattainable.

Even the actual shifts in the ideals of democracy do not lead to an adequate response due to the lack of faith in the political ideals, put forward by the authorities, and in the possibility of their implementation. It seems that most of events of last years at the $20^{\text {th }}$ the beginning of the $21^{\text {st }}$ century occur "outside people's soul".

Another ethical collision associated with the concepts of "we" and "they" forms the main nerve of ethical issues in individual and political morality. "We" are those who do not have authority, consider themselves "ordinary people", and "they" are those who have this power and control it. The content of political morality of "we" corresponds to something explicit, official, subject to legal control; "they" corresponds to something secret, informal, falling out of the field of legal relations. However, if a big part of social relations falls out of the field of social and legal control, it indicates the inadequacy of the social system to social practice. In a moderate amount this inadequacy can be compensated by political morality, in excessive - it leads to a decomposition of political morality, destruction of a social system. The facts of immorality of high power representatives are perceived as moral indulgence for the wider population, expressed in deviation from taxation, from licensing of professional activity, in avoidance of laws, double accounting, cooperation between law enforcement bodies and shadow structures, etc. Until such a practice is recognized by the population as morally acceptable, we will not be able to speak about realization of social and law-governed state ideal at all.

One more collision, which becomes significant for political ethics formation, is connected with the growing claims of citizens to government administration for their participation in governing the state. The administration, in spite of the claims of citizens, seeks to push people out of the politics, while trying to create the illusion of their participation in it. For this purpose, the general forms of citizens' participation in politics are 
cultivated: elections, referendums, and other political actions, through which people are involved in a political domain. Quasi-politics covers the entire domain of state bonds with society, all types of political thinking. However, if political functions exist within certain forms, then individuals are forced to use abstract criteria. People do not analyze the fact that the political forms of social existence are created before their birth, they exist beyond the will and consciousness of individuals. An individual can only choose, guided by their political ideal (if any). By contributing to the policy of ruling forces, people can get their share of power: to become a party or state figure, a member of government administration, and so on. In turn, power is distributed among individuals. Of course, people can receive their share of power in case of not sharing the policy of ruling circles as well, but simply striving for a certain status in society. And this is a matter of ethical order. Many random people come to power, and political ethics presupposes the presence of moral convictions and responsibility for their actions. First of all, this applies to professional politicians who must proceed not from for considerations of momentary advantages, but to think by state categories, to compare their actions with moral values and norms, to evaluate the consequences of their actions. Therefore, the moral culture of a politician involves not only professionalism in work, but also exceptional respect for interests of the country and its citizens, the ability to use the power rationally, to behave with the opponents and the opposition in a democratic way, to be able to compromise, defending the state and civil positions fundamentally. Evidence of the moral integrity of state and public-political leaders is their high strong-willed qualities, ability to adhere to the unity of words and actions, to show realism in evaluating their own results and state policy, intolerance to incompetence, dogmatism, and stagnation.

One of the lessons of Ukrainian development as an independent state can be the conclusion that the mandatory condition for progressive transformations is changes in citizen's consciousness and morality, which occur gradually and spontaneously, but under the goal-oriented state educational influence. Such influence should be made not as party propaganda or ideological suggestion, but should be an independent and important branch of state and government policy. Not only the stage of transformation of society, but also its further stable and balanced existence on the principles of high morality, justice and law require the 
permanent functioning of the national system of civic education and high morality. The formation of culture of critical loyalty and constitutional education, the civil socialization of personality is the main task and content of such system in Ukraine.

Socio-political morality is a somewhat different cultural phenomenon than an individual one: it belongs to another domain, has other criteria and norms. However, one can not ignore their interconnection and interdependence. If the members of society are immoral, the society will be the same. The moral climate of Ukraine is influenced by malice, theft, hooliganism, drunkenness, untidiness, and unpunctuality. For example, the majority of Ukrainian political parties declare their desire to adhere to moral and ethical values, since morality and culture are indispensable and important conditions for the development of statehood and civil society. But in that case why, over the years of independence, Ukraine has not made significant progress in its economic and cultural development, although according to some Western experts, after the collapse of the USSR it had significant economic and political potential sufficient to enter a number of leading countries of the world? Today, according to some indicators, our country is approaching third world countries, but not the leading world states.

Respect for a person, moral and physical dignity, inviolability of property, rights are not at the appropriate level. This is due to the fact that the ethics of individualism, interpreted as selfishness in our country, was blamed in Ukrainian ethos. The reason for this is the weak formation of a rationalized individual moral consciousness due to the priority of family ties of national culture with its tradition of transferring the center of attention from the individual to the group; in weakening the ability to moral self-identification, which causes an underdevelopment of awareness of the individual conscience category and self-worth of human views.

Relying on moral pluralism (the view that recognizes the plurality of value relations, obligations and life plans that are often incompatible), this theory provides for the necessity of a person to make a choice between what they consider to be morally correct and morally wrong. Moral pluralism does not require tolerance for morally wrong things, reconciliation of good and evil. The state can make people adhere to worthy forms of living based on ethical norms not by forced measures, but and at the same time it can discourage them to adhere to a morally 
unacceptable way of life, eliminating the conditions that make it attractive. Therefore, it should not use the coercion to stop "self-worthy" persons from unacceptable activities until they harm others.

The state recognition of personality's self-worthiness, however, gives it the right to use coercion, so that no harm is done to other people, because its task is to provide people with real opportunities for personal life and realization of a self-worthy position. It can forcefully interfere with the autonomy of some persons to protect the autonomy of others. At the same time, the state can not interfere in their autonomy for any other reason. The fundamental moral justification of personality's selfworthiness and the principle of moral pluralism must become an important aspect of political ethics based on tolerance, and not neutrality.

The current background of the political ethics formation is characterized by the disorder of the external and internal life of nation, the high proportion of the secret, the superiority of power of law over ethics, quasi-politics, etc., causing deep structural imbalances and impeding the formation of civil society. Solving problems in different domains of our society is complicated by the fact that the acquisition of state independence took place simultaneously with social transformation, the transformation of public structures from authoritarian-bureaucratic or even authoritarian-etatist forms to the state called "an open society", the state of a democratic, pluralistic, dynamic, law-governed, etc.

In addition, independence was sometimes perceived as simplified, one-sided, as a separation from the traditional community, rather than as an independence of internal social governance, aimed at radically renewal of the deep principles of public life. This, the complication of external political and economic relations as well, and finally, serious mistakes in public governance, generated by a number of reasons, both objective and subjective, led to the fact that the emergence of Ukrainian sovereignty was accompanied by a deep economic crisis, an incredible decline in people's prosperity, aggravation of social problems, crisis of morality and civic consciousness.

These negative factors led to the emergence of social tension, the spread of nihilism and pessimism, which greatly devalued the idea of national sovereignty and identity of the historical progress of Ukraine in the consciousness of certain layers of Ukrainian population. 
The discrepancies between the ideals and the realities of our society are determined by underdevelopment of political and social ethics. Failure to perform official duties, unrealized transactions, unpaid wages, unpaid taxes, ignored laws and public interests - all this is the difference between the ideal and social reality. To eliminate it means to restore the moral health of society.

In a democratic society, political ethics is one of the important dimensions of political life; it serves as an integral component of stability of a political system, an essential indicator of the society development and its political consciousness.

Ukrainian people's movement to the formation of a sovereign and independent state, the revival and development of national culture requires a new ideology, namely, the ideology of national revival, harmony, community and joint creation work of people living at the territory of Ukraine and beyond. The fundamental ideas of national harmony ideology have been achieved through much suffering from the contradictory development of Ukrainian cultural and national traditions, living in the minds, feelings and will of the majority of people, political programs of most political parties. However, they have not yet received a theoretically balanced and systematic representation as a humanitarian strategy for state building and cultural revival of nation.

The current problems of state building and national-cultural revival of Ukraine require careful study and deep understanding of the achievements of Ukrainian thinkers of different times regarding the nature and ways of resolving the Ukrainian national issue. The national revival has nothing to do with the isolation attitudes and thoughts that have always been inherent in some part of the Ukrainian intelligentsia.

The main reason for many negative phenomena in contemporary Ukrainian society is the lack of developed common morality, based on Soviet totalitarian values which are the things of the past. So, it is under the present conditions that the development and formation of a new system of moral and spiritual values, a new worldview that would be based on deep cultural and spiritual traditions of our people, are very important. Spiritual moral, religious values are the foundation of society, its living origins. If they exist, if they fill the souls of people, so no crises are terrible, people can confidently look into the future. It is impossible to overcome the socio-economic crisis until we find salvation from 
desolation in the minds and hearts of people, until the morality will fill the hearts of not only ordinary citizen, but also responsible political figure of any level. Economics and politics, according to our deep conviction, are secondary to culture, spirituality and morals. Therefore, one who thinks that it is necessary to revive the economy, postponing the revival of culture, education, spirituality, morality to some day is wrong. First, the national culture, "the spirit of people" should be restored, and then, based on it, the economy should be developed.

The formation of ideologies of national revival is a kind of philosophical paradigm of state and cultural construction, a problem which solution requires a collective effort of the intellectual elite of Ukraine. Careful acquaintance with the cultural and historical tradition of Ukrainians shows that the first things among others are the ideas of social, national harmony, cooperation of nations and states, conscientious work, unity, spirituality, ecology and health care.

Considering the main factors strengthening the role of moral principles in the Ukrainian society, one can not ignore such factor as mentality of Ukrainian people. Some researchers note that Ukrainian person is characterized by an extravagant attitude to the world, associated with such features as isolation, silent nature, the desire for spiritual seclusion, subordination, tolerance, certain life asceticism, unpretentiousness, high sensuality, domination of sensuality over intellectual and volitional. Such traits as features of a good person are truly inherent in Ukrainian people, but we must not forget that, as noted by other ancient thinkers, there is nothing more terrible than a good person brought to despair. It is such manifestations that we observed on the eve of and in the days of Khmelnytsky, Ruins, Kolyivshchyna, Ukrainian Revolution of the early 20th century.

The political mentality of Ukrainian people acts as an organizing factor, uniting political-psychological and national-cultural community of people. It is inextricably linked with worldview moral and ethical orientations of Ukrainian people, is reflected in the political consciousness of Ukrainians, and manifests itself as a unity of spiritual, sensual, emotional and effective forms of people's political existence. Therefore, the so-called stereotyping is unacceptable, according to which the psychological features of the nation are derived solely from the individual 
features of its individual members, which inevitably leads to misconceptions about national values in general.

At the same time, the mentality and national character of Ukrainians also contain such archetypes and features that adversely affect the development of political national establishment, political thinking and political practice. Researchers name an absolute predominance in the structure of social, group and private interests over national and social ones as one of the typical features of political mentality of Ukrainian people, especially of political elite, which led to the adoption of a stereotype of socio-psychological behavior of egocentric orientation in it. $\mathrm{N}$. Yakovenko notes that objective difficulties of people's political existence are intensified by subjective, ingrained in the inertial psychology of a Ukrainian who tends to passive waiting rather than to the position of action.

Unfortunately, in the public consciousness of a large part of Ukrainian people, and in the ideological doctrines of some political figures, such approach to Ukrainian history has not been overcome by this time, when all the troubles of the Ukrainian people are explained by external factors: by the Tatar-Mongol conquest at one time, the Lithuanian and Polish domination, Turkish-Tatar invasions, for a long time, and to this day, by Russian policy. According to this approach, a simplified image of the enemy is made, not taking into account complicated relationships and influences by Ukrainian people and our neighbors. Overestimation of external factors leads to underestimation of the internal ones, both political and moral-spiritual factors which in opinion of some researchers have been decisive in the development of Ukrainian people.

As K. Jaspers and A. J. Toynbee note, in the history of every people there is its "axial time", which is an age of development (including through the adaptation of borrowed ideas) of an adequate ideological, worldview, moral and ethical "response" to the challenge of new living conditions. The true basis of people's unity is spirit, public morality, and not a generic, natural or economic unity. It is they who ensure integrity, unite people in the common aspiration to freedom. ${ }^{4}$

There may be no more urgent problem for Ukraine as a sovereign state than returning to the general civilization path of human development. Ukraine proclaimed its independence as a declaration of its choice: to

\footnotetext{
${ }^{4}$ Ясперс К. Философская вера // Смысл и назначение истории. - СПб: Наука, 2000. - 272 с.
} 
return to the circle of the world history. The destiny gave Ukrainians another socio-historical chance. It is important not to lose it, not to drown it in the interlacement of side socio-political and economic collisions and troubles, defending illusory priorities and protecting utopian projects.

The general civilization change has no alternatives, but there are problems, first of all, the theoretical substantiation of social life dominant principles, to which one should return in order to make up for lost social time.

However, independent Ukraine is continuing its establishment and consolidation in the world. Its people are making considerable efforts to develop those successes and progressive tendencies in this situation, which inevitably will lead Ukraine into a number of highly developed European countries.

So, an important component of the strengthening of moral principles in Ukrainian society is the revival of national spirit, national consciousness, based on a national idea, which should lift moral standards and dignity of Ukrainians, promote their awareness of significance and value of our state as an integral part of European and world civilization.

Moral regulation is based on the presence of person's ability and capacity to comprehend the decision, the rational superiority of the option of an act and moral reflection, ensuring the maximum effectiveness of political activity, taking into account moral reasonableness. Any social action is considered as a result of interaction of various interests and needs, aspirations and will, without which it is impossible to understand the general orientation of historical events, and as a result, it is impossible to achieve a comprehensive study of issues of social transformative activity, the transition of society to higher levels of its development. All this requires the necessity for a comprehensive consideration of value orientations in political activity.

In fact, the socio-philosophical angle of view on value orientations is, first of all, in the awareness of their social significance. They act as an important bonding link between society (social environment) and individual, personality, and their internal world.

A holistic picture of public and political life can only be obtained if all three types of human activity stimuli are taken into account, taken in their correlation with the respective domains of daily life activity of society - material, social, political, and spiritual. Therefore, the very 
evaluation of the purpose and means of achieving such harmonious correlation depends on their interconnection.

And here the harmonious unity of morality and political reasonableness requires conscious creative efforts in all domains of human activity. The more objective the moral assessment of these efforts will be in this case, the closer it will be to the actual scientific assessment of public and political reality. Entering the most remote fields of political activity, moral evaluations act as one of the regulatory factors of political action, allowing us to combine faithful knowledge with the will to action.

\section{REFERENCES}

1. Огієнко Іван. Українська культура. Коротка історія культурного життя українського народа. - К.: Абрис, 1991. - 272 с.

2. Бебик В. Наша політична культура // Політологічні читання. 1992. - №1. - C. 18-24.

3. Ясперс К. Философская вера // Смысл и назначение истории. СПб: Наука, 2000. - 272 с.

4. Філософський енциклопедичний словник / Ред. кол. B.I. Шинкарук та інш. - К.: Абрис, 1983. - 815 с.

5. Феномен української культури: проблеми методології дослідження. - К.: Генеза, 1999. - 520 с.

6. Філософія політики: Короткий енциклопедичний словник / Ред. кол.: Губерський Л.В. (керівник та інш.); Авт. упорядник.: Андрущенко В.П. (керівник) та інші. - К.: Знання України, 2002. $670 \mathrm{c}$.

\section{Information about the author: Tymoshenko T.S.}

Candidate of Philosophical Sciences, Assistant Professor at the Department of Philosophy and History Educational-Scientific Humanitarian Institute V. I. Vernadsky Taurida National University, 33, Ivana Kudri str., Kyiv, 01042, Ukraine. 